\title{
Leaf optical properties as affected by shade in saplings of six tropical tree species differing in successional status
}

\author{
Rogéria Pereira Souza and Ivany F. M. Válio*
}

Departamento de Fisiologia Vegetal, Instituto de Biologia, Universidade Estadual de Campinas, CP 6109, CEP 13083-970, Campinas, SP, Brasil; *Corresponding author: ivalio@bol.com.br

Received: 06/10/2002, Accepted: 03/01/2003

Tree species differing in successional status may present different responses to shade. Adjustments at leaf level may affect their optical properties, leading to changes in PAR (photosynthetically active radiation) absorbance. The aim of this study was to evaluate leaf optical properties as affected by understory shade in saplings of six tropical tree species differing in successional status and degree of shade tolerance. Chlorophyll content and specific leaf area (SLA) were also evaluated. The effects of shade on leaf optical properties and chlorophyll content differed among the studied species, whereas increased SLA was a common response for all species, reflecting the occurrence of thinner leaves under shade. The three studied shade-tolerant species - Esenbeckia leiocarpa, Myroxylon peruiferum and Hymenaea courbaril presented a greater PAR absorbance under shade. The response of the shade-intolerant species was varied. While Schizolobium parahyba also showed a greater PAR absorbance under shade, Chorisia speciosa did not alter its spectral properties and Cecropia pachystachya presented an opposite pattern, with smaller absorbance under shade. Increases in leaf chlorophyll content were significant in the shade-tolerant species, whereas they were absent or of small magnitude in the shade-intolerant ones. Although the shade-induced decrease of leaf reflectance was the only response that safely discriminated tolerant from intolerant species, the adjustments in leaf chlorophyll content and optical properties were more consistent for the tolerant species.

Key words: Chlorophyll, leaf absorbance, shade tolerance, specific leaf area, successional species.

\begin{abstract}
Alterações das propriedades ópticas de folhas em resposta a sombreamento em plantas jovens de seis espécies arbóreas tropicais pertencentes a diferentes estádios de sucessão: Espécies arbóreas tropicais pertencentes a diferentes estádios de sucessão podem apresentar diferentes respostas ao sombreamento. Ajustes apresentados ao nível das folhas podem afetar as propriedades ópticas, levando a alterações na absorbância da radiação fotossinteticamente ativa (RAF). O objetivo deste trabalho foi avaliar alterações das propriedades ópticas foliares em resposta ao sombreamento natural em plantas jovens de seis espécies arbóreas tropicais pertencentes a diferentes estádios de sucessão e com diferente grau de tolerância à sombra. Conteúdo de clorofila e área foliar específica (AFE) também foram avaliados. Os efeitos do sombreamento sobre as propriedades ópticas foliares e conteúdo de clorofila diferiram entre as espécies estudadas, ao passo que o aumento da AFE foi uma resposta comum, refletindo a ocorrência de folhas mais finas. As três espécies tolerantes à sombra - Esenbeckia leiocarpa, Myroxylon peruiferum e Hymenaea courbaril - apresentaram uma maior absorbância da RAF sob sombreamento. A resposta das espécies intolerantes à sombra foi variada. Enquanto Schizolobium parahyba também apresentou maior absorbância da RAF sob sombreamento, Chorisia speciosa não alterou suas propriedades espectrais e Cecropia pachystachya apresentou um padrão oposto de resposta, com menor absorbância sob sombreamento. Aumentos no conteúdo de clorofila foram significativos nas espécies tolerantes à sombra, ao passo que estiveram ausentes ou foram de pequena magnitude nas intolerantes. Embora a redução da reflectância foliar sob sombreamento tenha sido a única resposta que discriminou seguramente as espécies tolerantes das intolerantes, os ajustes no conteúdo de clorofila e nas propriedades ópticas das folhas foram mais consistentes para as espécies tolerantes.
\end{abstract}

Palavras-chave: absorbância foliar, área foliar específica, clorofila, espécies sucessionais, tolerância à sombra. 
Studies on sun/shade acclimation have, in the last decades, focused on growth and/or photosynthetic alterations presented by tree species differing in successional status. Generally, late-successional shadetolerant species show only a limited response to shade compared with the greater adjustments of earlysuccessional light-demanding species (Osunkoya et al., 1994; Chazdon et al., 1996; Lee et al., 1996; Souza, 1996; Strauss-Debenedetti and Bazzaz, 1996). At the leaf level, adjustments to shade may involve, among others, alterations in leaf thickness and chlorophyll content (Lei et al., 1996; Lei and Lechowicz, 1997; Evans and Poorter, 2001). These leaf characteristics are important in determining leaf optical properties (Vogelmann, 1993), a topic which has been relatively less investigated. Some studies revealed no marked differences in leaf optical properties between groups of sun and shade species (Lee and Graham, 1986; Knapp and Carter, 1998) or between exposed and shaded leaves of particular species (Langenheim et al., 1984; McKiernan and Baker, 1991; Cao, 2000). Other studies, however, have found that, in shade tolerant species, a greater adjustment of leaf characteristics is presented, which can lead to a higher absorbance of photosynthetically active radiation (PAR) under the light-limited conditions of understories (StJacques et al., 1991; Poorter et al., 1995). The objective of this study was to evaluate leaf optical properties as affected by shade in saplings of six tropical tree species differing in successional status and degree of shade tolerance.

The study was carried out with the early-successional species Cecropia pachystachya Trec., Schizolobium parahyba (Vell.) Blake, the intermediate species Chorisia speciosa St. Hil. and the late-successional Esenbeckia leiocarpa Engl., Myroxylon peruiferum L.F. and Hymenaea courbaril L. The first three species can be considered shade-intolerant, whereas the three latter are shadetolerant, based on their survival behavior under deep shade (Souza and Válio, 2001). Species will be designated by the genus name throughout. Plants were grown from seeds germinated under controlled conditions (constant light, PAR $\left.14 \mu \mathrm{mol} \cdot \mathrm{m}^{-2} \cdot \mathrm{s}^{-1}\right)$. Seedlings were transplanted into trays and kept in a greenhouse until establishment. Once established, the seedlings were transplanted into $3.5 \mathrm{dm}^{3}$ polyethylene bags filled with forest soil and were submitted either to full sun (FS) or natural shade (NS) treatments under field conditions. The field experiments were carried out at Santa Genebra Reserve, an $2.52 \mathrm{~km}^{2}$ area of semideciduous tropical vegetation situated in Campinas,

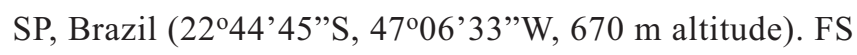
treatment consisted of exposing plants to full sun radiation in an open area adjacent to the forest, whereas in the NS treatment, plants were kept inside the forest under the shade imposed by the closed canopy. Irradiance under the shade treatment was $0.4 \%$ to $2.4 \%$ of full sun. Red/far-red ratio was 0.23 to 0.74 within the forest and 1.22 to 1.44 outside. Both measurements were carried out with a LI-1800 portable spectroradiometer (LI-COR). In the FS treatment, the bags were kept inside ditches in soil to avoid excessive heating of the root system. FS plants were watered daily and NS plants were watered when necessary. After approximately $100 \mathrm{~d}$, plants were evaluated for leaf optical properties, chlorophyll content and specific leaf area (SLA).

Leaf reflectance and transmittance were recorded with a LI-1800-12S integrating sphere linked through a fiber optic cable to a LI-1800 portable spectroradiometer (LICOR) at $400-750 \mathrm{~nm}$ in $2 \mathrm{~nm}$ intervals. Leaf absorbance was calculated as 1 - reflectance - transmittance. The measurements were performed for three leaves (two for Esenbeckia) from different plants of each species. Leaf chlorophyll content was measured from $80 \%$ acetone extracts according to Arnon (1949) and calculated on an area basis. Duplicated samplings from four plants per treatment were used. SLA was calculated as the ratio area/ dry mass for five (Myroxylon), seven (Schizolobium) or ten (all other species) leaves of plants grown under each treatment. Data were analyzed through the Student $t$ test or, in cases where it was not applicable, by the Wilcoxon test, both at $5 \%$ level of probability.

The effects of understory shade on leaf optical properties and chlorophyll content differed among species, whereas increased SLA was a common response, despite being comparatively less accentuated in the three shade tolerant species, i.e., Esenbeckia, Myroxylon and Hymenaea (table 1). Increased SLA reflects the occurrence of thinner leaves, which are less costly to produce (Lee and Graham, 1986), being a frequent response observed to shade (Cao, 2000; Lee et al., 2000; Evans and Poorter, 2001). Increases in chlorophyll content (mass basis) are also an adaptive and common response to shade, since they can provide a higher light harvesting capacity in low-light environments (Lei et al., 1996; Lei and Lechowicz, 1997). 
Nonetheless, chlorophyll content on an area basis although also reported in some studies (Lei and Lechowicz, 1997; Lee et al., 2000) - can even be lower in shaded than in sunlit leaves due to the occurrence of thinner leaves in the former condition (Lee et al., 1990; Tinoco-Ojanguren and Pearcy, 1995). Here, despite the reduced leaf thickness under shade, a significantly higher total chlorophyll content (area basis) was found in four species - Chorisia, Esenbeckia, Myroxylon and Hymenaea (table 1). The increase in chlorophyll content was very marked for the latter three shade-tolerant species, whereas it was of a very small magnitude in Chorisia. For Cecropia and Schizolobium, total chlorophyll content was similar under both growth conditions (table 1). Except for Schizolobium, all other species also presented decreases in the chlorophyll $\mathrm{a} / \mathrm{b}$ ratio under shade, as observed for a number of species in other studies (Cao, 2000; Lee et al., 2000; Rosevear et al., 2001). Examples of no modifications or even increases in this ratio have also been reported, showing that, although common, the reduction in chlorophyll $\mathrm{a} / \mathrm{b}$ is not an universal response (Murchie and Horton, 1997). The decreases in chlorophyll a/ $\mathrm{b}$ ratio reflect a greater thylakoid stacking, which is likely to lead to a somewhat greater efficiency of light utilization under light-limited conditions (Anderson et al., 1988).

Table 1. Specific leaf area (SLA), chlorophyll content and chlorophyll a/b ratio of plants of Cecropia pachystachya, Schizolobium parahyba, Chorisia speciosa, Esenbeckia leiocarpa, Myroxylon peruiferum and Hymenaea courbaril grown under full sun (FS) and natural shade (NS) treatments. Values, within a species, followed by the same letter are not significantly different at $p \leq 0.05$.

\begin{tabular}{|c|c|c|c|c|c|c|}
\hline \multirow{2}{*}{ Species } & \multirow{2}{*}{ Treatment } & \multirow{2}{*}{$\begin{array}{c}\text { SLA } \\
\left(\mathrm{dm}^{2} \cdot \mathrm{g}^{-1}\right)\end{array}$} & \multicolumn{3}{|c|}{ Chlorophyll content (mg.cm-2) } & \multirow{2}{*}{$\begin{array}{l}\text { Chlorophyll } \\
\text { a/b ratio }\end{array}$} \\
\hline & & & Chlorophyll a & chlorophyll b & total & \\
\hline \multirow[t]{2}{*}{ Cecropia pachystachya } & FS & $1.70 \mathrm{~b}$ & $0.029 \mathrm{a}$ & $0.011 \mathrm{a}$ & $0.039 \mathrm{a}$ & $2.65 \mathrm{a}$ \\
\hline & NS & $4.43 \mathrm{a}$ & $0.025 \mathrm{~b}$ & $0.011 \mathrm{a}$ & $0.036 \mathrm{a}$ & $2.37 \mathrm{~b}$ \\
\hline \multirow[t]{2}{*}{ Schizolobium parahyba } & FS & $2.23 \mathrm{~b}$ & $0.028 \mathrm{a}$ & $0.021 \mathrm{a}$ & $0.049 \mathrm{a}$ & $1.35 \mathrm{~b}$ \\
\hline & NS & $5.61 \mathrm{a}$ & $0.032 \mathrm{a}$ & $0.013 \mathrm{~b}$ & $0.046 \mathrm{a}$ & $2.42 \mathrm{a}$ \\
\hline \multirow[t]{2}{*}{ Chorisia speciosa } & FS & $2.31 \mathrm{~b}$ & $0.020 \mathrm{a}$ & $0.007 \mathrm{~b}$ & $0.027 \mathrm{~b}$ & $2.80 \mathrm{a}$ \\
\hline & NS & $4.94 \mathrm{a}$ & $0.021 \mathrm{a}$ & $0.008 \mathrm{a}$ & $0.030 \mathrm{a}$ & $2.50 \mathrm{~b}$ \\
\hline \multirow[t]{2}{*}{ Esenbeckia leiocarpa } & FS & $1.86 \mathrm{~b}$ & $0.022 \mathrm{~b}$ & $0.008 \mathrm{~b}$ & $0.030 \mathrm{~b}$ & $2.69 \mathrm{a}$ \\
\hline & NS & $3.47 \mathrm{a}$ & $0.042 \mathrm{a}$ & $0.017 \mathrm{a}$ & $0.059 \mathrm{a}$ & $2.44 \mathrm{~b}$ \\
\hline \multirow[t]{2}{*}{ Myroxylon peruiferum } & FS & $0.71 \mathrm{~b}$ & $0.027 \mathrm{~b}$ & $0.010 \mathrm{~b}$ & $0.036 \mathrm{~b}$ & $2.76 \mathrm{a}$ \\
\hline & NS & $0.86 \mathrm{a}$ & $0.031 \mathrm{a}$ & $0.013 \mathrm{a}$ & $0.043 \mathrm{a}$ & $2.44 \mathrm{~b}$ \\
\hline \multirow[t]{2}{*}{ Hymenaea courbaril } & FS & $1.57 \mathrm{~b}$ & $0.026 \mathrm{~b}$ & $0.012 \mathrm{~b}$ & $0.038 \mathrm{~b}$ & $2.22 \mathrm{a}$ \\
\hline & NS & $1.81 \mathrm{a}$ & $0.051 \mathrm{a}$ & $0.026 \mathrm{a}$ & $0.080 \mathrm{a}$ & $1.56 \mathrm{~b}$ \\
\hline
\end{tabular}

The three shade-tolerant species Esenbeckia, Myroxylon and Hymenaea and the shade-intolerant Schizolobium presented a significant greater PAR absorbance under shade, mainly in the range 500-700 nm (figure 1). This was achieved through reductions either in leaf transmittance (e.g. Schizolobium), in leaf reflectance (e.g. Esenbeckia and Myroxylon) or in both (e.g. Hymenaea) (table 2). In the latter three shade-tolerant species, the greater absorbance values may be, at least partially, explained by their increased chlorophyll content associated with their comparatively smaller reduction of leaf thickness, the latter being a characteristic which is expected to bring an increase in leaf transmittance (Osborne and Raven, 1986; Tanner and Eller, 1986). Probably, in these species, the increase in the chlorophyll content was sufficient to more than offset the reduction in leaf thickness and the resulting tendency of higher transmittance. The occurrence of consistent relationships between PAR absorbance or reflectance and chlorophyll concentration (area basis) has been demonstrated elsewhere (Syvertsen et al., 1995; Evans and Poorter, 2001). However, the occurrence of other alterations in leaf structure, which 
can contribute to maximize the effective pathlength of radiation within the leaf and thereby increase the probability of its absorption by photosynthetic pigments, can not be disregarded. Probably, this was the case for Schizolobium, whose increased leaf absorbance was not associated with an increased chlorophyll content. Accompanying the increases in PAR absorbance in these species, an absorbance increase in wavelengths a little beyond $700 \mathrm{~nm}$ was also registered, as demonstrated by the integrated values calculated for the range $700-750 \mathrm{~nm}$ (table 2). This fact was also noted in the study of St-Jacques et al. (1991). Lee and Graham (1986) presented data showing that plants can use quanta beyond $700 \mathrm{~nm}$ in photosynthesis. Considering the far-red enriched spectral quality of the shaded understory, the utilization of quanta in the range 700-750 $\mathrm{nm}$ may be an important response to increase the overall carbon gain of the plants (Lee and Graham, 1986).

The shade-intolerant species Chorisia practically did not alter the spectral properties of their leaves under shade (figure 1, table 2), although an increase in the chlorophyll content was observed (table 1). This increase, however, was of a small magnitude and probably not enough to provide a greater absorbance. In comparison with the other species, the shade-intolerant Cecropia plants presented an opposite pattern of alteration in their leaf optical properties, with smaller absorbance and higher transmittance under shade (figure 1, table 2). This species did not show increases in chlorophyll content (table 1). Therefore, Cecropia plants seem to be unable to adjust their leaf anatomy and chlorophyll content in order to compensate the reduced leaf thickness and consequently increased transmittance under shade. This lack of response may be unfavorable for their maintenance in deeply shaded environments.

Owing to the response of Schizolobium, the shadeinduced increases in leaf absorbance did not allow a clear discrimination between the studied shade-intolerant and tolerant species, although they were a more consistent response in the latter group. On the other hand, the shadeinduced decreases in leaf reflectance safely discriminated the two groups, being significant for the shade-tolerant species and absent in the shade-intolerant ones (table 2). Probably, this response was associated with the comparatively greater adjustments in the chlorophyll content presented by the tolerant species. These results may agree with St-Jacques et al. (1991) and Poorter et al. (1995),

Table 2. Integrated values of leaf absorbance, transmittance and reflectance of plants of Cecropia pachystachya, Schizolobium parahyba, Chorisia speciosa, Esenbeckia leiocarpa, Myroxylon peruiferum and Hymenaea courbaril grown under full sun (FS) and natural shade (NS) treatments. Values followed by the same letter are not significantly different at $\mathrm{p}<0.05$.

\begin{tabular}{|c|c|c|c|c|c|c|c|}
\hline \multirow{3}{*}{ Species } & \multirow{3}{*}{ Treatment } & \multicolumn{6}{|c|}{ Integrated values (relative units) } \\
\hline & & \multicolumn{3}{|c|}{400 - $750 \mathrm{~nm}$ waveband } & \multicolumn{3}{|c|}{700 - $750 \mathrm{~nm}$ waveband } \\
\hline & & Absorbance & Transmittance & Reflectance & Absorbance & Transmittance & Reflectance \\
\hline \multirow[t]{2}{*}{ Cecropia pachystachya } & FS & 275.08 a & $32.97 \mathrm{~b}$ & $41.92 \mathrm{a}$ & $15.12 \mathrm{a}$ & $15.96 \mathrm{~b}$ & $18.92 \mathrm{a}$ \\
\hline & NS & $255.77 \mathrm{~b}$ & $47.03 \mathrm{a}$ & $47.15 \mathrm{a}$ & $13.41 \mathrm{~b}$ & $18.65 \mathrm{a}$ & $17.93 \mathrm{a}$ \\
\hline \multirow[t]{2}{*}{ Schizolobium parahyba } & FS & $261.11 \mathrm{~b}$ & $30.50 \mathrm{a}$ & $58.36 \mathrm{a}$ & $13.34 \mathrm{~b}$ & $15.69 \mathrm{a}$ & $20.97 \mathrm{a}$ \\
\hline & NS & 287.36 a & $23.52 \mathrm{~b}$ & $39.09 \mathrm{a}$ & $15.98 \mathrm{a}$ & $14.23 \mathrm{a}$ & $19.78 \mathrm{a}$ \\
\hline \multirow[t]{2}{*}{ Chorisia speciosa } & FS & $268.00 \mathrm{a}$ & $42.30 \mathrm{a}$ & $39.66 \mathrm{a}$ & $12.22 \mathrm{a}$ & $19.66 \mathrm{a}$ & $18.11 \mathrm{a}$ \\
\hline & NS & $264.80 \mathrm{a}$ & $46.46 \mathrm{a}$ & 39.57 a & $12.56 \mathrm{a}$ & $20.38 \mathrm{a}$ & $17.71 \mathrm{a}$ \\
\hline \multirow[t]{2}{*}{ Esenbeckia leiocarpa } & FS & $259.60 \mathrm{~b}$ & $35.43 \mathrm{a}$ & $54.93 \mathrm{a}$ & $9.65 \mathrm{~b}$ & $18.00 \mathrm{a}$ & $22.35 \mathrm{a}$ \\
\hline & NS & 287.96 a & $30.60 \mathrm{a}$ & $37.44 \mathrm{~b}$ & $17.42 \mathrm{a}$ & $16.13 \mathrm{a}$ & $17.09 \mathrm{~b}$ \\
\hline \multirow[t]{2}{*}{ Myroxylon peruiferum } & FS & $279.39 \mathrm{~b}$ & $28.90 \mathrm{a}$ & $41.68 \mathrm{a}$ & $15.88 \mathrm{~b}$ & $15.74 \mathrm{a}$ & $18.38 \mathrm{a}$ \\
\hline & NS & 295.46 a & $22.50 \mathrm{a}$ & $32.02 \mathrm{~b}$ & $20.60 \mathrm{a}$ & $14.58 \mathrm{a}$ & $14.81 \mathrm{~b}$ \\
\hline \multirow[t]{2}{*}{ Hymenaea courbaril } & FS & $269.71 \mathrm{~b}$ & $37.82 \mathrm{a}$ & $42.44 \mathrm{a}$ & $12.03 \mathrm{~b}$ & $19.25 \mathrm{a}$ & $18.71 \mathrm{a}$ \\
\hline & NS & $284.88 \mathrm{a}$ & $27.14 \mathrm{~b}$ & $37.95 \mathrm{~b}$ & $15.88 \mathrm{a}$ & $16.49 \mathrm{a}$ & $17.63 \mathrm{a}$ \\
\hline
\end{tabular}


that suggested that a greater leaf plasticity is related to species shade tolerance. Accordingly, Lee et al. (2000) showed a great plasticity for leaf characters in a shade-tolerant species. So, whereas shade tolerant species usually show less extent of response to shade for several growth and photosynthetic parameters, the reverse trend seems to occur in relation to the chlorophyll content and leaf optical properties, which may contribute to a greater capacity to maximize light harvesting under deep shade. Such capacity may be important for the successful exploitation of understory environments.

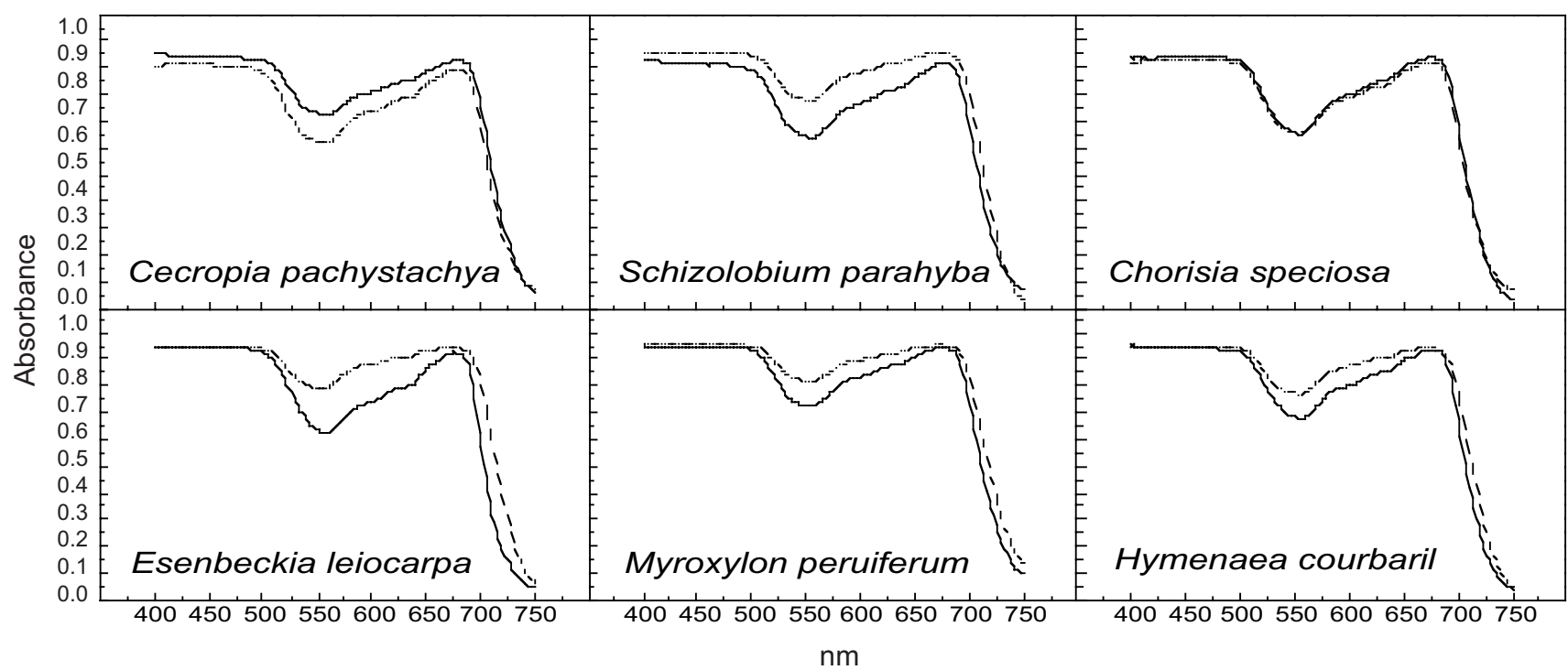

Figure 1. Leaf absorbance in Cecropia pachystachya, Schizolobium parahyba, Chorisia speciosa, Esenbeckia leiocarpa, Myroxylon peruiferum and Hymenaea courbaril plants grown under full sun (solid lines) and natural shade (dashed lines) treatments.

Acknowledgements: We thank Dr. Jurandir Zullo Junior for helping with the spectroradiometer measurements and Dr. Ladaslav Sodek for reviewing the English version of the manuscript. We also thank Fundação José Pedro de Oliveira for permission to work at the Santa Genebra Reserve. R.P. Souza was supported by CAPES.

\section{REFERENCES}

Anderson JM, Chow WS, Goodchild DJ (1988) Thylakoid membrane organisation in sun/shade acclimation. Aust. J. Plant Physiol. 15:11-26.

Arnon DJ (1949) Copper enzymes in isolated chloroplasts polyphenoloxidases in Beta vulgaris. Plant Physiol. 24:1-15.

Cao K-F (2000) Leaf anatomy and chlorophyll content of 12 woody species in contrasting light conditions in a Bornean heath forest. Can. J. Bot. 78:1245-1253.

Chazdon RL, Pearcy RW, Lee DW, Fetcher N (1996) Photosynthetic responses of tropical forest plants to contrasting light environments. In: Mulkey SS, Chazdon RL, Smith AP (eds) Tropical Forest Plant Ecophysiology, pp.5-55. Chapman and Hall, New York, USA.
Evans JR, Poorter H (2001). Photosynthetic acclimation of plants to growth irradiance: the relative importance of specific leaf area and nitrogen partitioning in maximizing carbon gain. Plant Cell Environ. 24:755-767.

Knapp AK, Carter GA (1998) Variability in leaf optical properties among 26 species from a broad range of habitats. Am. J. Bot. 85:940-946.

Langenheim JH, Osmond CB, Brooks A, Ferrar PJ (1984) Photosynthetic responses to light in seedlings of selected Amazonian and Australian rainforest tree species. Oecologia 63:215-224.

Lee DW, Graham R (1986) Leaf optical properties of rainforest sun and extreme shade plants. Amer. J. Bot. 73:1100-1108.

Lee DW, Bone RA, Tarsis SL, Storch D (1990) Correlates of leaf optical properties in tropical forest sun and extreme shade plants. Amer. J. Bot. 77:370-380.

Lee DW, Baskaran K, Mansor M, Mohamad H, Yap SK (1996) Irradiance and spectral quality affect asian tropical rain forest tree seedling development. Ecology 77:568-580.

Lee DW, Oberbauer SF, Johnson P, Krishnapilay B, Mansor M, Mohamad H, Yap SK (2000) Effects of irradiance and spectral quality on leaf structure and function in seedlings of two southeast Asian Hopea (Dipterocarpaceae) species. Am. J. Bot. 87:447-455. 
Lei TT, Lechowicz MJ (1997) Functional responses of Acer species to two simulated forest gap environments: leaflevel properties and photosynthesis. Photosynthetica 33:277-289.

Lei TT, Tabuchi R, Kitao M, Koike T (1996) Functional relationship between chlorophyll content and leaf reflectance, and light-capturing efficiency of Japanese forest species. Physiol. Plant. 96:411-418.

McKiernan M, Baker NR (1991) Adaptation to shade of the light-harvesting apparatus in Silene dioica. Plant Cell Environ. 14:205-212.

Murchie EH, Horton P (1997) Acclimation of photosynthesis to irradiance and spectral quality in British plant species: chlorophyll content, photosynthetic capacity and habitat preference. Plant Cell Environ. 20:438-448.

Osborne BA, Raven JA (1986) Light absorption by plants and its implications for photosynthesis. Biol. Rev. 61:1-61.

Osunkoya OO, Ash JE, Hopkins MS, Graham AW (1994) Influence of seed size and seedling ecological attributes on shade-tolerance of rain-forest tree species in northern Queensland. J. Ecol. 82:149-163.

Poorter L, Oberbauer SF, Clark DB (1995) Leaf optical properties along a vertical gradient in a tropical rain forest canopy in Costa Rica. Am. J. Bot. 82:1257-1263.

Rosevear MJ, Young AJ, Jonhson GN (2001) Growth conditions are more important than species origin in determining leaf pigment content of British plant species. Funct. Ecol. 15:474-480.
Souza RP, Válio IFM (2001) Seed size, seed germination and seedling survival of Brazilian tropical tree species differing in successional status. Biotropica 33:447-457.

Souza RP (1996) Germinação, crescimento, atividade fotossintética e translocação de compostos de carbono em espécies arbóreas tropicais: estudo comparativo e influência de sombreamento natural. Campinas, Universidade Estadual de Campinas. Tese de Doutorado.

St-Jacques C, Labrecque M, Bellefleur P (1991) Plasticity of leaf absorbance in some broadleaf tree seedlings. Bot. Gaz. 152:195-202.

Strauss-Debenedetti S, Bazzaz FA (1996) Photosynthetic characteristics of tropical trees along successional gradients. In: Mulkey SS, Chazdon RL, Smith AP (eds) Tropical Forest Plant Ecophysiology, pp.162-186. Chapman and Hall, New York, USA.

Syvertsen JP, Lloyd J, McConchie C, Kriedemann PE, Farquhar GD (1995) On the relationship between leaf anatomy and $\mathrm{CO}_{2}$ diffusion through the mesophyll of hypostomatous leaves. Plant Cell Environ. 18:149-157.

Tanner V, Eller BM (1986) Epidermis structure and its significance for the optical properties of leaves of the Mesembryanthemaceae. J. Plant Physiol. 125:285-294.

Tinoco-Ojanguren C, Pearcy RW (1995) A comparison of light quality and quantity effects on the growth and steady-state and dynamic photosynthetic characteristics of three tropical tree species. Funct. Ecol. 9:222-230.

Vogelmann TC (1993) Plant tissue optics. Annu. Rev. Plant Physiol. Plant Mol. Biol. 44:231-251. 